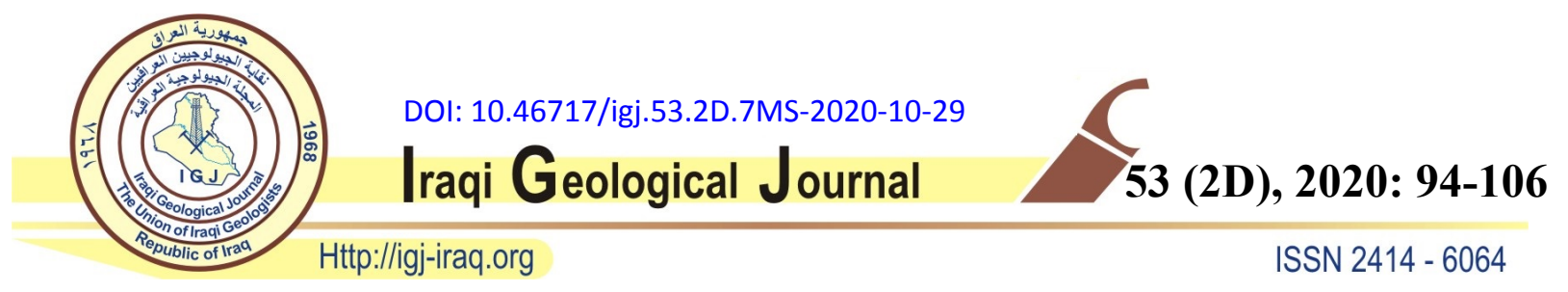

\title{
SPECIFIC ASSESSMENT OF FINE AGGREGATES FROM DIBDIBBA FORMATION AT TAR AL-SAYED IN KARBALA (MIDDLE OF IRAQ) AS CONSTRUCTION MATERIALS
}

\author{
${ }^{1}$ Khaled Ahmed Abdullah Alhadad" and ${ }^{1}$ Humam Thair Saeed Alrawee \\ ${ }^{1}$ Department of Applied Geology, College of Science, University of Tikrit, Iraq \\ "E-mail: KhaledAlhadad@yahoo.com \\ Received: 14 May 2020; accepted: 24 August 2020
}

\begin{abstract}
This research deals with assessing fine aggregate (sand) properties as construction materials, that were collected from the Dibdibba Formation at Tar AL-Sayed, Karbala, Iraq, in mortar, concrete, tiles, thermo-stone, solid, hollow masonry blocks and cement paste. Physical tests were carried out on five samples, the moisture content, specific gravity, density of both bulk, dry and porosity were almost varied. The tested samples show that they are unsuitable for all types of concrete, tiles types, thermo-stone and cement masonry block in terms of grain size in all fractions except that of $4.75 \mathrm{~mm}$ and $2.36 \mathrm{~mm}$. Later all samples were treated by washing using fresh water, fine clean sand was added in an attempt to form a convenient type for all construction works. The total dissolved solids (1.67 - 4.53\%), gypsum content (0.64-2.13\%), organic matters $(0.71-2.01 \%), \mathrm{Cl}^{-}(0.11-0.81 \%)$ and $\mathrm{pH}(7.51-7.91)$ are ranged within the global standards (ASTM, USCS, BS, and IQS). Quartz is predominated mineral, albite and gypsum are of moderate abundance, whereas mica and calcite occurred as traces.
\end{abstract}

Keywords: Injana Formation; Tiles; Masonry block; Thermo-stone; Clean sand

\section{INTRODUCTION}

Iraq is one of many countries which it has a wide desert, it consists of plenty amounts of sand, particularly distributed in the Mesopotamian plain, the Tigris and Euphrates riverbanks, and its branches, geological formations such as the Dibdibba Formation which is exposed in the middle and south of Iraq. The study area is characterized by dry weather, high temperature $\left(35 \mathrm{C}^{\circ}\right.$ as average) in summer, wind speed $(3.9 \mathrm{~m} / \mathrm{s})$. In winter, low temperature $\left(10 \mathrm{C}^{\circ}\right)$, rainfall average $(16 \mathrm{~mm})$ and wind speed average $(1.9 \mathrm{~m} / \mathrm{s})(\mathrm{IMO}, 2014)$. Tar Al-Sayed is located about $30 \mathrm{~km}$ to 
the west of Karbala between longitude $43^{\circ} 52^{`} 30^{\prime \prime}-43^{\circ} 55^{`} 30^{\prime} \mathrm{E}$, and Latitude $32^{\circ} 37^{`} 30^{\prime \prime}-32^{\circ} 39^{`} 10^{\prime} \mathrm{N}$ (Fig. 1.).

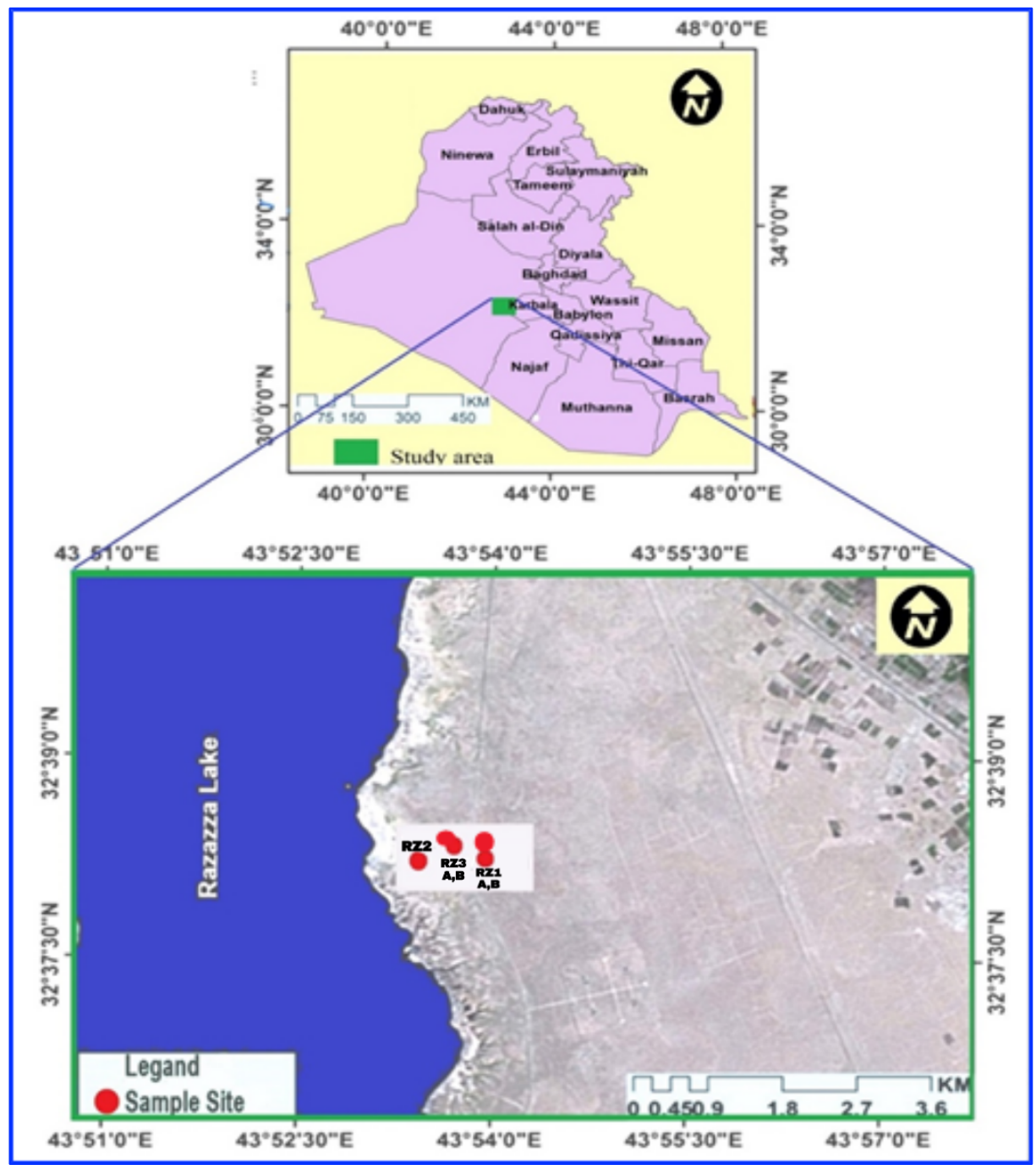

Fig. 1. The location map of the study area

The research aims to determine the suitability of the fine aggregate occurred in the Dibdibba Formation. Several previous studies were carried out on fine aggregate in the Dibdibba Formation. The clastic of the Dibdibba Formation are originated from the Arabian Shield deposited in a fluviatile environment (Sadik, 1977; Awadh and Al-Ankaz, 2016). Bulgur-Gunmen (1980) has assessed the Dibdibba Formation for the construction materials. Al-Hadad and Al-Jwaynee (2010) mentioned that the fine aggregate from selected sites in the middle of Iraq at each of Tuz, Alalam, Senyah, Anbar, and Karbala Alekaydeer are suitable to be used as construction materials like concrete, tiles and mortar, but after removing gypsum, and soft materials. 


\section{GEOLOGICAL SETTING}

\section{Dibdibba Formation (Pliocene - Pleistocene)}

Macfadyen (1938) described the Dibdibba Formation for the first time in an ideal section in AlBargesiah area in the south desert of Iraq. Hassan (2007) described the Dibdibba Formation in Karbala, Najaf and middle of Iraq, upper part is exposed in Tar Al-Sayed and Tar Najaf, which formed main plateau, with a thickness ranges $1-18 \mathrm{~m}$. It is formed from, sand and pebbly sand, sand colors are brown, gray, yellow, white, and yellowish brown (Fig. 2). The Quaternary sediments are overburden deposits formed from aeolian deposits, which are sand sheets, and sand dunes present in Karbala and Najaf Plateau. Most sand dunes type in the study area is Nabkah sand dune which is characterized by fine gains (Al-Tawash, 1966). Valleys fill sediments product from activity of seasonal rivers, which cross Razzaza Lake, it is a base sorted mixture of silt, sand, and pebbles (Al-Shamari, 2018). Alluvial sediments existed as a long-restricted zone at the lower part of Tar AL-Sayed, derived from erosion of the Injana and Dibdibba formations (Awadh et al., 2013). The study area is located on the unstable shelf between Mesopotamian and Salman zone, at the Abu Jir fault, Euphrates zone represents the boundary between stable zone and unstable zone (Awadh et al., 2018). Henson (1951) and Al- Amiri, (1979) indicated presence linear structure toward NW-SE. Geomorphology of the study area according to, Al-Khateeb, and Hassan (2005) exposed many features like Najaf- Karbala Plateau, Razzaza depression, and rock cliffs slope.

\section{MATERIALS AND METHODS}

\section{Field Work}

First step included many tours in the study area that are started on 8 March 2018, by which sampling sites were determined. Second step, five samples $(1,2,3,4,5)$ or (RZ1-A, RZ1-B, RZ2, RZ3-A, RZ3-B) were collected. Many field works were also documented by photographs (Plate 1). The coordinates of the study area were determined by GPS.

\section{Petrographic and X-Ray Diffraction Tests}

Samples were tested by using the polarized microscope and XRD that were prepared in the Department of Geology, College of Science, University of Baghdad, and Iraqi Geological Survey.

\section{Chemical Analysis}

Total dissolved solids (TDS), gypsum content, organic matter content, chloride $\left(\mathrm{Cl}^{-}\right)$, and $\mathrm{pH}$ according to $\mathrm{Nu}$ et al. (2020) and Shekel et al. (1999) were carried out in Chemical Engineering Department, Engineering Factuality, Tikrit University. 


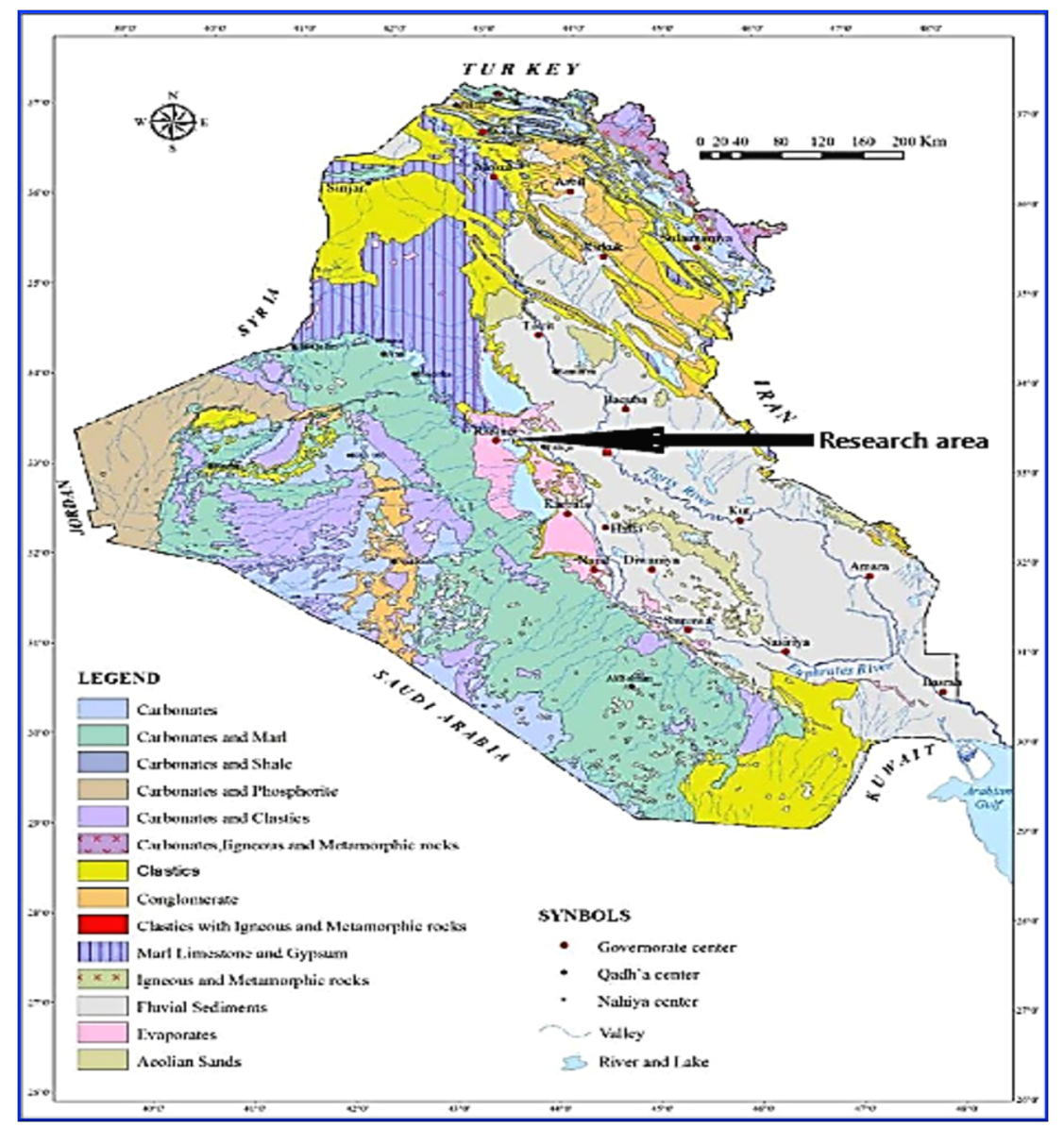

Fig. 2. Iraqi lithological map (Sissakian and Bader, 2012)

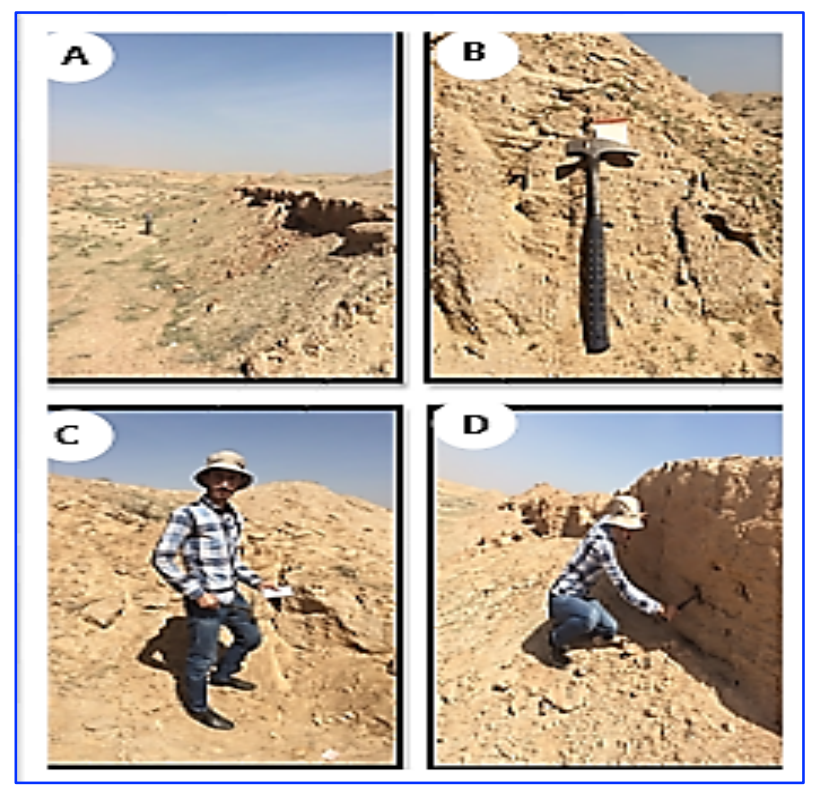

Plate 1. Field work 


\section{Physical Tests}

Moisture content, density, grain size, specific gravity, and porosity were done according to ASTMC-33-02 (2004) and carried out in laboratory of Applied Geology Department, College of Sciences, Tikrit University.

The physical tests include:

\section{Moisture content (mc)}

Moisture content was determined according to ASTM D2216-98 (2004) using equation 1

$$
m_{c}=\frac{w_{w}}{w_{d}} * 100 \%
$$

Where: $\mathrm{m}_{\mathrm{c}}=$ moisture content, $\mathrm{W}_{\mathrm{w}}=$ weight of water, $\mathrm{Wd}=$ weight of dry sample

\section{Specific gravity Gs}

The Gs was computed according to ASTM D854-02 (2004) using equation 2.

$$
G_{s} \text { at } C^{\circ}=W_{3} /\left(W_{1}+W_{3}\right)-W_{2}
$$

$\mathrm{W}_{1}=$ Weight of distilled water + Weight of Volumetric flask, Where: $\mathrm{W}_{2}=$ Weight of mixture $\mathrm{W}_{2}=$ sample (water + soil) + Weight of Vol. flask

$\mathrm{W}_{3}=$ Weight of dry sample

Gs at $\mathrm{C}^{\circ}$ corrected according equation 3.

$$
G_{S} T_{20}=G_{S} T_{1}
$$

GsT1 $=$ Specific gravity at Initial temperature $(18-30) \pm 1$.

GsT20=Specific gravity at standard (20) temperature.

$\mathrm{A}=$ Heat correction coefficient.

\section{Bulk and dry densities (dry Unite Weight) $Y_{B}$ and $Y_{d}$}

Bulk and dry densities was computed according to ASTM C788-7 (2017). (Wilun, and Starzewski, 1975) using equation 4.

$$
\mathrm{\gamma} \boldsymbol{B}=(\text { BulkWeight gm }) /(\text { Volume cm3 }), \gamma \boldsymbol{d}=\operatorname{dry}(\text { Weight gm. }) / \text { Volumecm3 }) \text { (4) }
$$




\section{Porosity n\%}

Porosity was calculated mathematically according to equation 5 .

$$
n \%=\left(1-\gamma d / G_{s}\right) * 100
$$

\section{Grain Size Analysis}

The graded ratio of sand was measured by sieving mechanically. Sand classification depends on its grading (ASTM-D, 422-63, 2004) sand do not presence individual material, it mixed with pebbles, and fine soil. Grains were separated from each other using sieve analysis in order to determine sands ratios (ASTM D 2487-06, 2014; Lambe and Whitman., 1969). Data represent the American standard (Fig. 3).

\section{RESULTS AND DISSCUSSION}

Results are presented in Table 1. Values mc, Gs, Ув and Уd, are low-moderate based on results of mineralogical composition. Porosity values (28.677- 40.008\%) increase with friable and exposed sand. The climate parameters (evaporate, temperature, and rainfall) affect on some physical properties. Grain size results pointed to unsuitability of the raw material based on the standard of construction works, unless treatments take place. Chemical analysis results showed fitting with standards, only gypsum values appear unaccepted ( $>0.5 \%)$. XRD in Fig.5 clarifies that quartz is dominant to very dominant, albite and gypsum are moderate, and calcite is rare. Thin sections under plane polarized microscope shows same mineralogical composition that are identified by XRD (Plates 2 and 3). Treatment of the fine aggregate by washing with a tape water to remove or reduce gypsum and soft materials, then added clean fine graded sand according to fineness equation, so this treatment is recommended.

\section{Treatments}

Samples are classified coarse sand according to standards (Table1, and Fig.3.) Unsuitable, so treatment be necessary. Washed raw material by fresh tape water to remove gypsum and added fine clean sand, to balanced grading ratios, equations 6 and 7. (ASTM C 33/C33- M13, 2003) (Fine ness modules).

$$
\begin{aligned}
& F M=R_{1} F M_{1}+R_{2} F M_{2} \\
& R_{1}+R_{2}=1
\end{aligned}
$$


Where: $\mathrm{FM}=$ fineness equation, $\mathrm{R}_{1} \mathrm{FM}_{1}=$ Coarse Sample fineness, $\mathrm{R}_{2} \mathrm{FM}_{2}=$ Fineness of fine sand, $\mathrm{R}_{1}=$ ratio of coarse sample and $\mathrm{R}_{2}=$ ratio of fine sand. Noticed Table 2 and Fig. 6 showed samples curve after treatment, it be suitable for construction works.

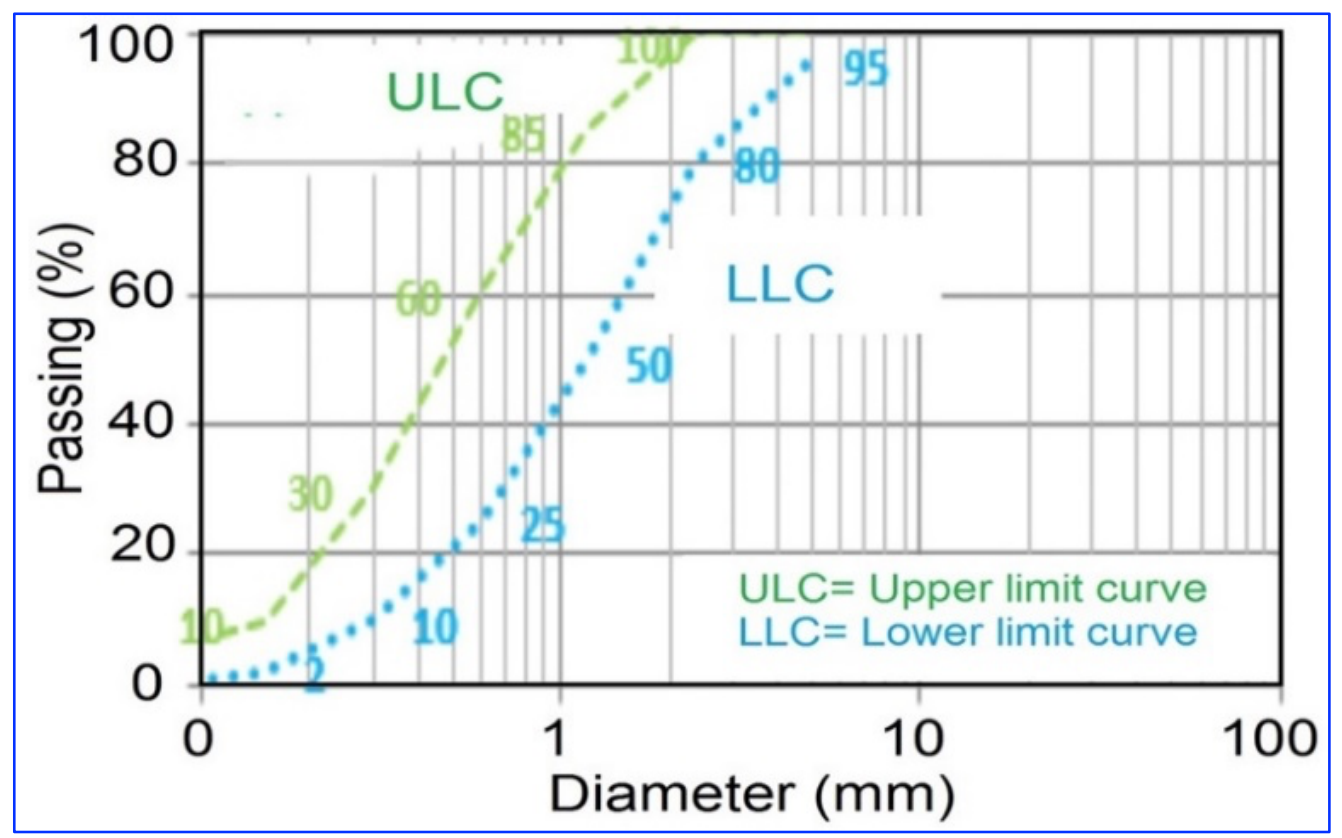

Fig. 3. American standard of fine aggregate grading

Table 1. Results of some physical and chemical properties

\begin{tabular}{|c|c|c|c|c|c|}
\hline Samples & RZ1-A & RZ1-B & RZ2 & RZ3-A & RZ3-B \\
\hline $\mathrm{Mc}$ & 5.329 & 1.791 & 2.944 & 1.132 & 3.092 \\
\hline Gs & 2.227 & 2.069 & 2.070 & 2.229 & 2.070 \\
\hline $\mathrm{\gamma d}_{\mathrm{d}}$ & 1.366 & 1.455 & 1.477 & 1.455 & 1.355 \\
\hline $\mathrm{V}_{\mathrm{B}}$ & 1.644 & 1.666 & 1.622 & 1.688 & 1.655 \\
\hline $\mathrm{n} \%$ & 40.008 & 29.677 & 28.648 & 34725 & 34542 \\
\hline $4.75 \mathrm{~mm}$ & 100 & 99.36 & 99.55 & 99.55 & 99.47 \\
\hline $2.38 \mathrm{~mm}$ & 99 & 96.26 & 94.12 & 94.66 & 95.71 \\
\hline $1.18 \mathrm{~mm}$ & 93.1 & 84.34 & 82.41 & 78.49 & 82.5 \\
\hline $0.600 \mathrm{~mm}$ & 78.99 & 66.59 & 67.42 & 58.7 & 64.55 \\
\hline $0.300 \mathrm{~mm}$ & 36.11 & 40.49 & 35.42 & 32.58 & 44.06 \\
\hline $0.150 \mathrm{~mm}$ & 16.89 & 6.48 & 15.55 & 11.2 & 11.99 \\
\hline $0.075 \mathrm{~mm}$ & 4.31 & 2.31 & 4.15 & 4.43 & 3.38 \\
\hline T.D. S & 2.31 & 1.67 & 3.15 & 4.53 & 2.03 \\
\hline Gypsum & 1.23 & 0.92 & 2.13 & 0.60 & 1.21 \\
\hline o.m.c & 1.88 & 2.01 & 0.96 & 1.97 & 0.71 \\
\hline $\mathrm{Cl}^{-}$ & 0.61 & 0.11 & 0.81 & 0.20 & 0.42 \\
\hline $\mathrm{pH}$ & 7.76 & $\begin{array}{l}7.83 \\
\end{array}$ & 7.51 & 7.91 & 7.62 \\
\hline
\end{tabular}

mc $=$ moisture content, Gs $=$ Specific gravity, $Y_{d}, Y_{B}=$ Dry, Bulk density, $n \%=$ Porosity 4.75mm - 0.075mm Grain diameters, T.D.S. = Total soluble salts, Gyp. \%= Gypsum content $\%$, o.m.c. $=$ Organic material content, $\mathrm{Cl}-=$ Chloride $\mathrm{Ion}$, and $\mathrm{pH}=$ Acidic index 


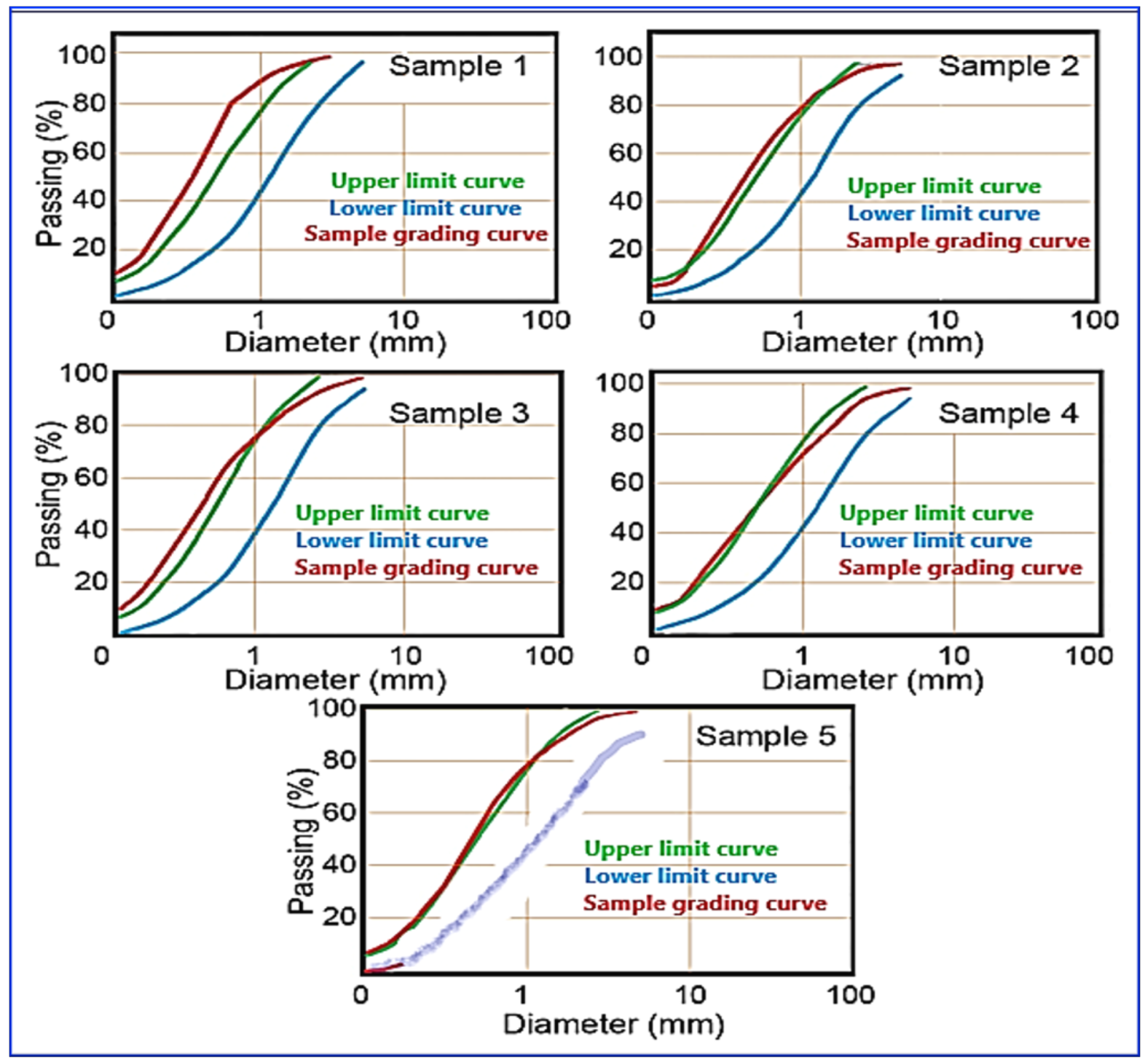

Fig. 4. Grain size curves of samples 


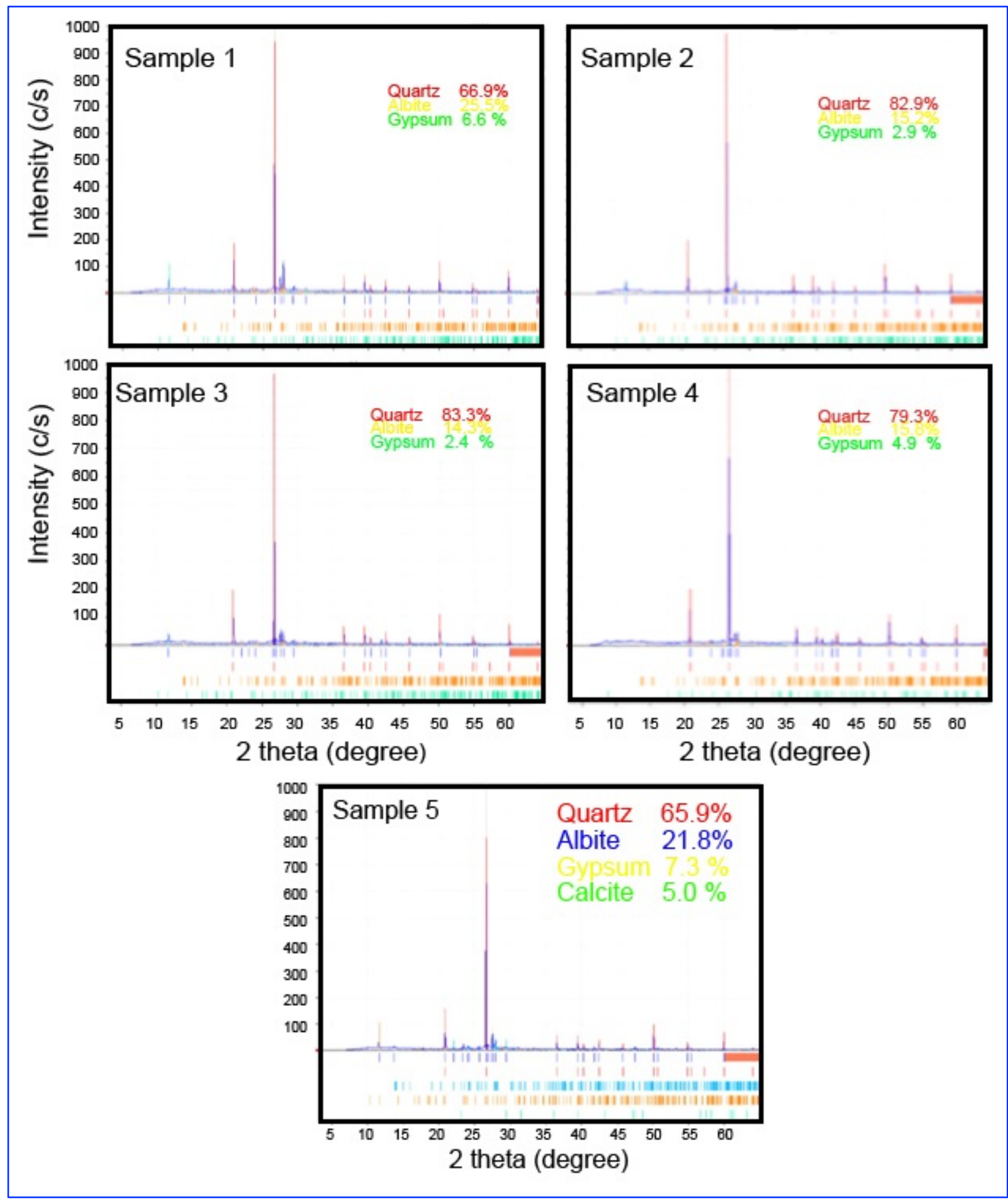

Fig. 5. X-ray diffraction of samples 

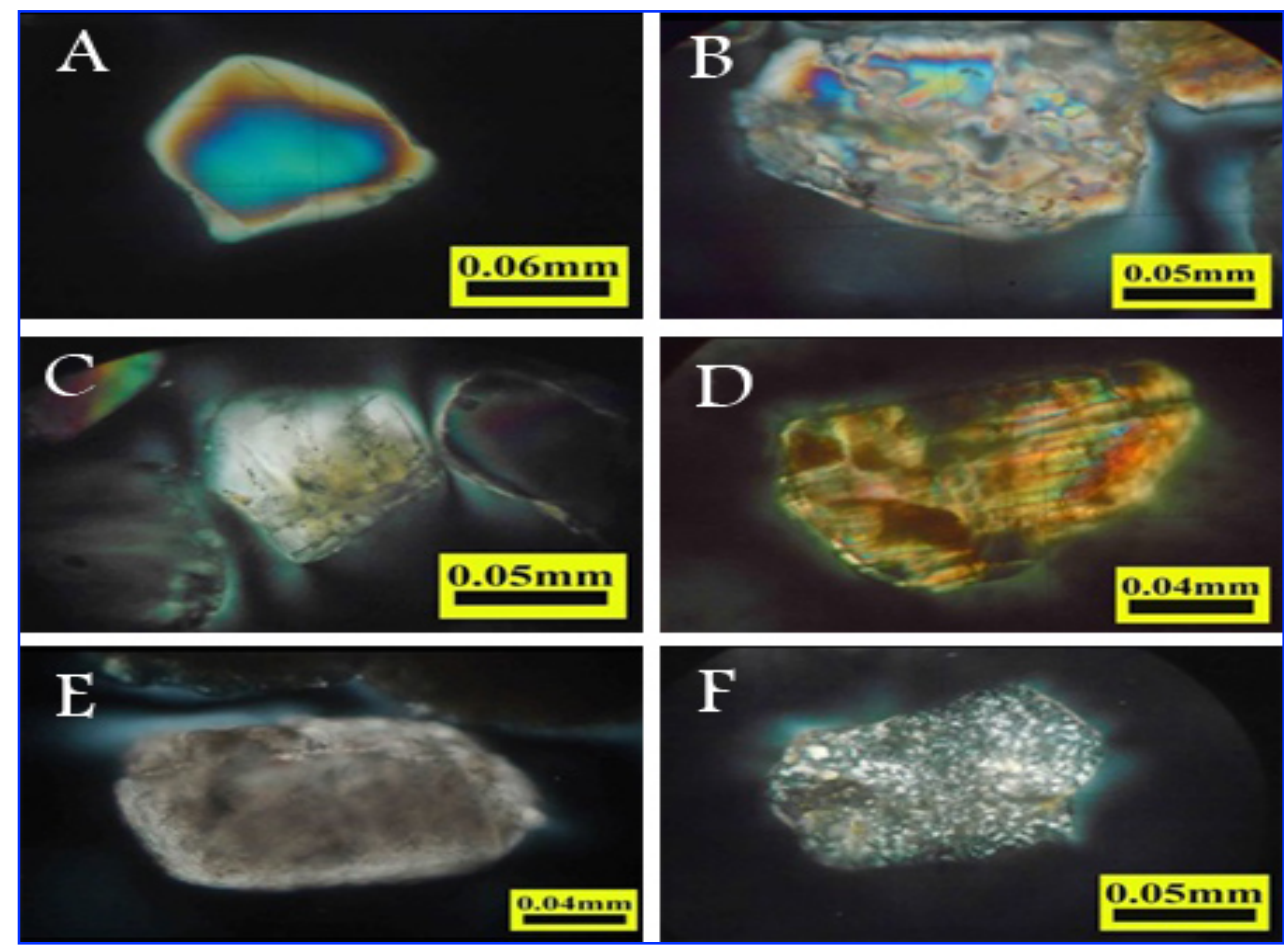

Plate 2. A, B; Mono, poly crystalline Quartz, C, D, F; Feldspar crystals, and E; carbonate

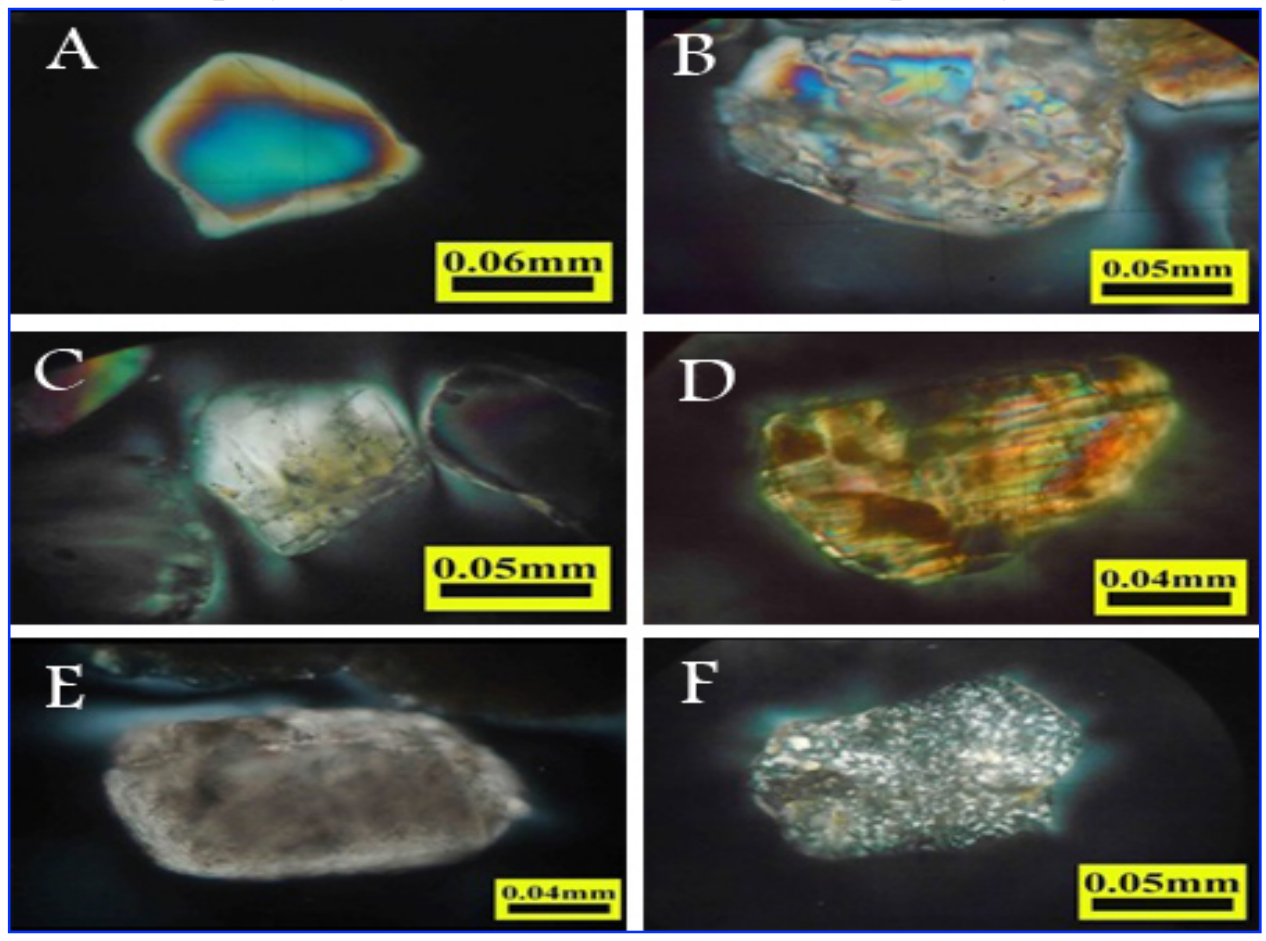

Plate 3. A; Chert rock, B; Igneous rock, C, D; Mudstone, metamorphic fragments, gypsum, quartz, and carbonate 
Table 2. F. M. upper, lower limits, $R_{1} F M_{1}, R_{2} F M_{2}$, ratios of sample and fine sand

\begin{tabular}{|l|c|c|c|c|c|}
\hline Samples & RZ1-A or 1 & RZ1-B or 2 & RZ-2 or 3 & RZ3-A or 4 & RZ3-B or 5 \\
\hline F.M.L L. & 3.38 & 3.38 & 3.38 & 3.38 & 3.38 \\
\hline F.M. Up. L. & 2.18 & 2.15 & 2.15 & 2.15 & 2.15 \\
\hline $\mathrm{R}_{1} \mathrm{FM}_{1}$ & 3.41 & 3.89 & 3.99 & 3.77 & 3.91 \\
\hline $\mathrm{R}_{2} \mathrm{FM}_{2}$ & $1.7-1.7 \mathrm{R}_{1}$ & $1.73-1.73 \mathrm{R}_{1}$ & $1.81-1.81 \mathrm{R}_{1}$ & $1.76-1.76 \mathrm{R}_{1}$ & $1.64-1.64 \mathrm{R}$ \\
\hline $\mathrm{R} 1$ & $42.5 \%$ & $49.5 \%$ & $36 \%$ & $51.75 \%$ & $51 \%$ \\
\hline R2 & $57.5 \%$ & $50.5 \%$ & $64 \%$ & $48.25 \%$ & $49 \%$ \\
\hline F.M.L. & - & 2.80 & 2.80 & 2.80 & 2.80 \\
\hline
\end{tabular}

F. M. L. L=Cumulative sum \% Lower limit $=3.38 \%$, F. M. Up. $L=C$ umulative sum $\%$ upper limit $=\mathbf{2 . 1 5 \%}$ $R_{1} F M_{1}=$ Coarse sand (sample) ratio, $R_{2} F M_{2}=$ Fine sand ratio and $F$. M. L. =Mean of sum lower, upper limits curves of standers

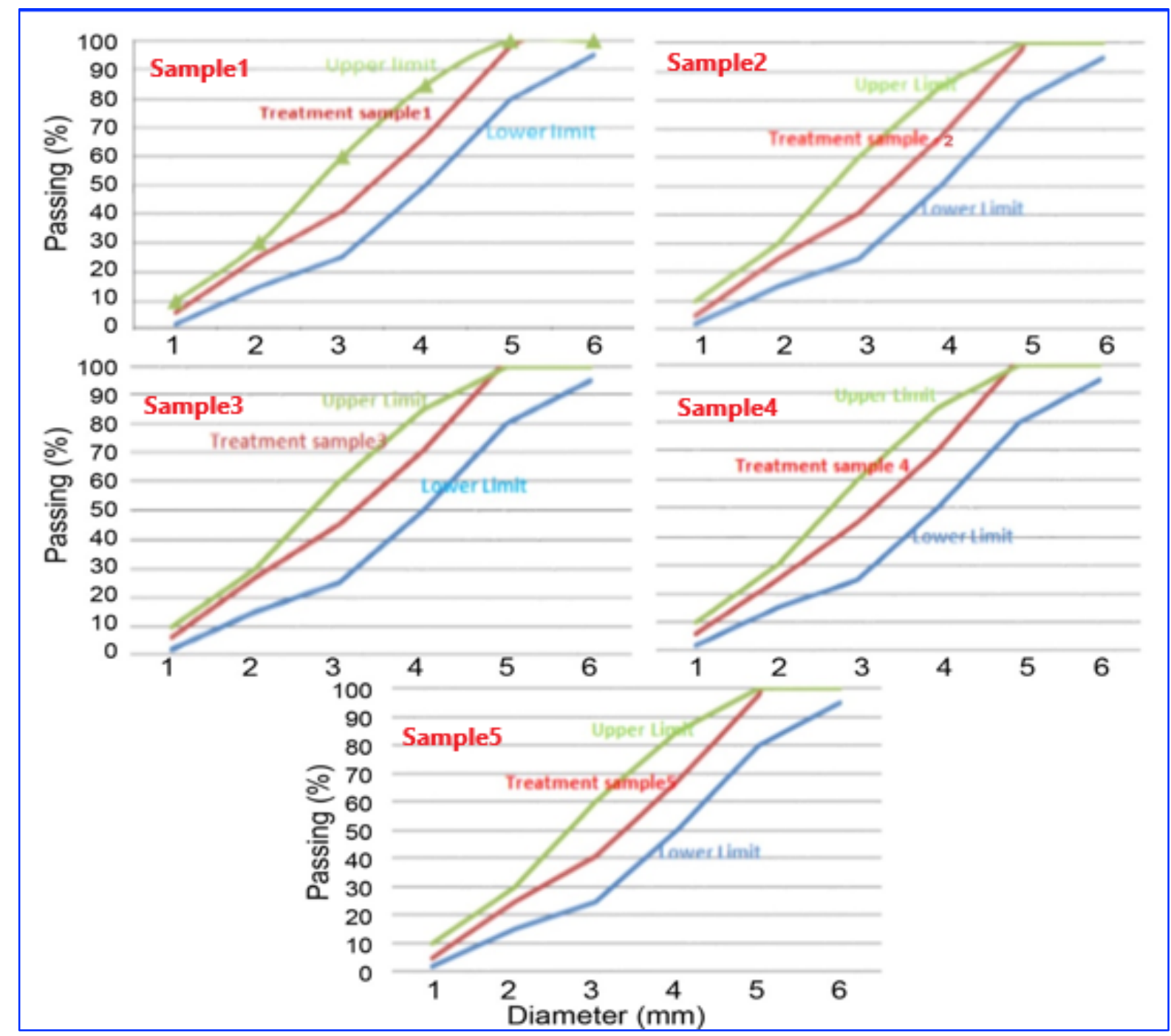

Fig. 6. Grain size curves of samples after treatments 


\section{CONCLUSIONS AND RECOMMENDATIONS}

\section{Conclusions}

1. Friable sand appears of low moisture content, and high - medium porosity.

2. Samples $1,2,3,4$, and 5 represented fine aggregates contain gypsum more than $0.5 \%$, it is not acceptable values, and need to remove gypsum.

3. Mineralogically, quartz is dominate to very dominate in all samples. Albite and gypsum are of moderate distribution, calcite in sample 5 is rare, therefore removed gypsum is important.

4. The $\mathrm{TDS} \%$, omc $\%, \mathrm{Cl}^{-} \%$ and $\mathrm{pH}$ value, are acceptable ratios and coincide with the standard. Gypsum content $\%$ is unacceptable.

5. Grain size results for all samples are unsuitable as raw materials.

6. Raw materials must be mixed with fine cleaned sand with a certain grading ratios added according to equations 6, 7 (ASTM, Fineness equation).

\section{ACKNOWLEDGMENTS}

At the end of research works, it must be thanks, Allah helps us during all period, then must thanks friends, who share us with samples collection, and laboratory tests, Dr. Hassan Kattof, Dr. Buthina Salman, Mr. Kames Mohsen, Mr. Ahmed Jumma, and Mr. Sinan Talib. The authors are very grateful to the Editor in Chief Prof. Dr. Salih M. Awadh, the Secretary of Journal Mr. Samir R. Hijab and the Technical Editor Dr. Heba S. Al-Mimar for their great efforts and valuable comments.

\section{REFERENCES}

Al- Amiri, H. M., 1979. Structural interpretation of the landsat imagery for the Southern Desert-Iraq, Int.report, SOM lib, 27p.

Al-Hadad, K. A. A. and Al-Jwaynee, Y. K. S., 2010. Specific assessment of fine aggregate (sand) from selected sites, middle Iraq, $5^{\text {th }}$ Science conference, College of Sciences, Babylon University, 5, (In Arabic)

Al-Khateeb, A. A. G., 1988. Geomorphological Study for Najaf Plateau, UN published MS c. Thesis, College of Sciences, Baghdad University, 120p. (In Arabic).

Al- Khateeb, A. A. G., and Hassan, K. M., 2005. Detailed geological survey for mineral exploration in Karbala- Najaf Area. GEOSURV. Baghdad. Iraq. Report, 2891:59P.

Al-Shamari, M.N.A., 2018. Geochemical Modeling of Ground water in the Dammam Formation south Razzaza Lake, middle of Iraq. Iraqi Geological Journal. 50 (1): 49-64.

Al-Tawash, B. S. M., 1996. The Pleistocene History of the Razzaza and Tharthar Depressions in Central Iraq, Ph.D. thesis, College of Science, University of Baghdad. (In Arabic), 124 p.

ASTM C33/C33M-13,-2003. Standard specification for Concrete aggregates, ASTM Int.2003.

ASTM D2216-98., 2004. Standard Test Method for Laboratory Determination of Water (Moisture) Content of Soil and Rock by Mass.

ASTM D854-02., 2004. Standard Test Methods for Specific Gravity of Soil Solids by Water Pycnio meter.

ASTM D422-63, 2004. Standard Test Method for Particle-Size Analysis of Soils. 
ASTM D2487-06, 2014. Standard Practice for Classification of Soils for Engineering Purposes (U. S. C. S Unified Soil Classification System).

ASTM C788-7, 2017. Dry unit weight of sand, American of standard for test and materials.

Awadh, S. M. and Al-Ankaz, Z, S., 2016. Geochemistry and petrology of Late Miocene-Pleistocene Dibdibba sandstone formation in south and central Iraq: implications for provenance and depositional setting. Arabian Journal of Geoscience, 9 (8) :1-14. DOI 10.1007/s12517-016-2558-8.

Awadh, S. M., Al-Bahadily, H., and Al-Ankaz, Z. S., 2018. Interpreting the tectonics of the Abu- Jir fault, KarblaNajaf plateau using mineralogical and geophysical data. Iraqi Bulletin of Geology and Mining, 14 (1): 47- 63.

Awadh, S. M. Abood, Z. S., and Eisa, M. J. 2013. Chemical and physical control processes on the development of caves in the Injana Formation, Central Iraq. Arabian Journal of Geoscience, 6:3765-3772. DOI $10.1007 / \mathrm{s} 12517-012-0637 \mathrm{z}$.

B.S.1377, 1990. Methods of Test for Soils for Civil Engineering Purposes. Chemical and Electro-Chemical Tests.

Bulgur-Gunmen, 1980. Assessed and sediments in Dibdibba Formation for construction materials.

Hassan, K. M., 2007. Stratigraphy of Karbala-Najaf Area, Central Iraq. Iraqi Bulletin of Geology and Mining, 3(2):53-62.

Henson, F. R. 1951. Oil Occurrence in Relation to Regional Geology of the Middle East. Geol. Soc. Tulsa. Iraqi Meteorological Organization (IMO), 2014. Climatical Data for Karbala Station, for period (1976-2014).

Lambe, T. W., and Whitman, R. V., 1969. Soil Mechanics, John Wiley and Sons. Inc. New York, 553p.

Macfadyen, J. A., 1938. Water supplies in Iraq, Ministry of Economics and Communication, 1: 232.

Nu, N. T., Dung, N. T., Son, B. T., and Thinh, P. H., 2020.investigation of salts, alum content, in the soils and their, effects on soil properties: case study, in coastal areas of Vietnam. Iraqi Geological Journal, 53(2A): 19-34.

Sadik, M. J., 1977. Study Area, by Many Sections, Represented Part of Dibdibba Formation in Safwan, and NajafKarbala Plateau, MSc, unpublished Thesis, College of Sciences, Baghdad University, in Arabic, 119p.

Shekel, N. N., Fareed, A. and Tomass, N., 1999. Chemical Standard. National construction center, Baghdad, Iraq. (In Arabic) 59p.

Sissakian, V. K., and Bader, Z., 2012. Iraqi Lithological map, University of Kurdistan - Hawler Iraq.

Wilun, Z., and Starzewski, K. 1975. Soil Mechanics in Foundation Engineering. Surry University Press London 